Nonradioactive Air Emissions

Modification to the Notice

of Construction for the

200 Area Effluent

Treatment Facility

Date Published

September 1996

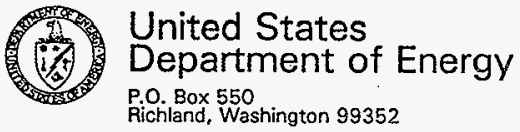


ITADEMAKS DSCLAM Th

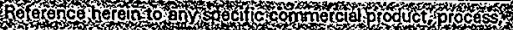

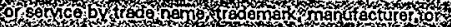

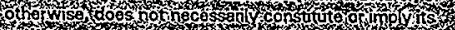

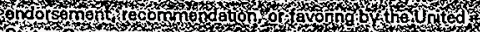

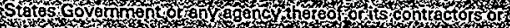

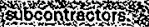

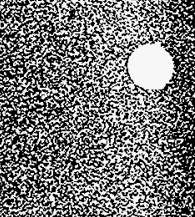

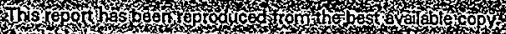

\% *

A A w

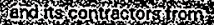

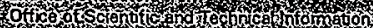

5. $0.30 \%$ :

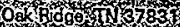

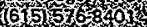

7.

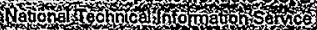

52851 .

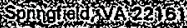

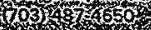

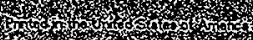

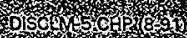




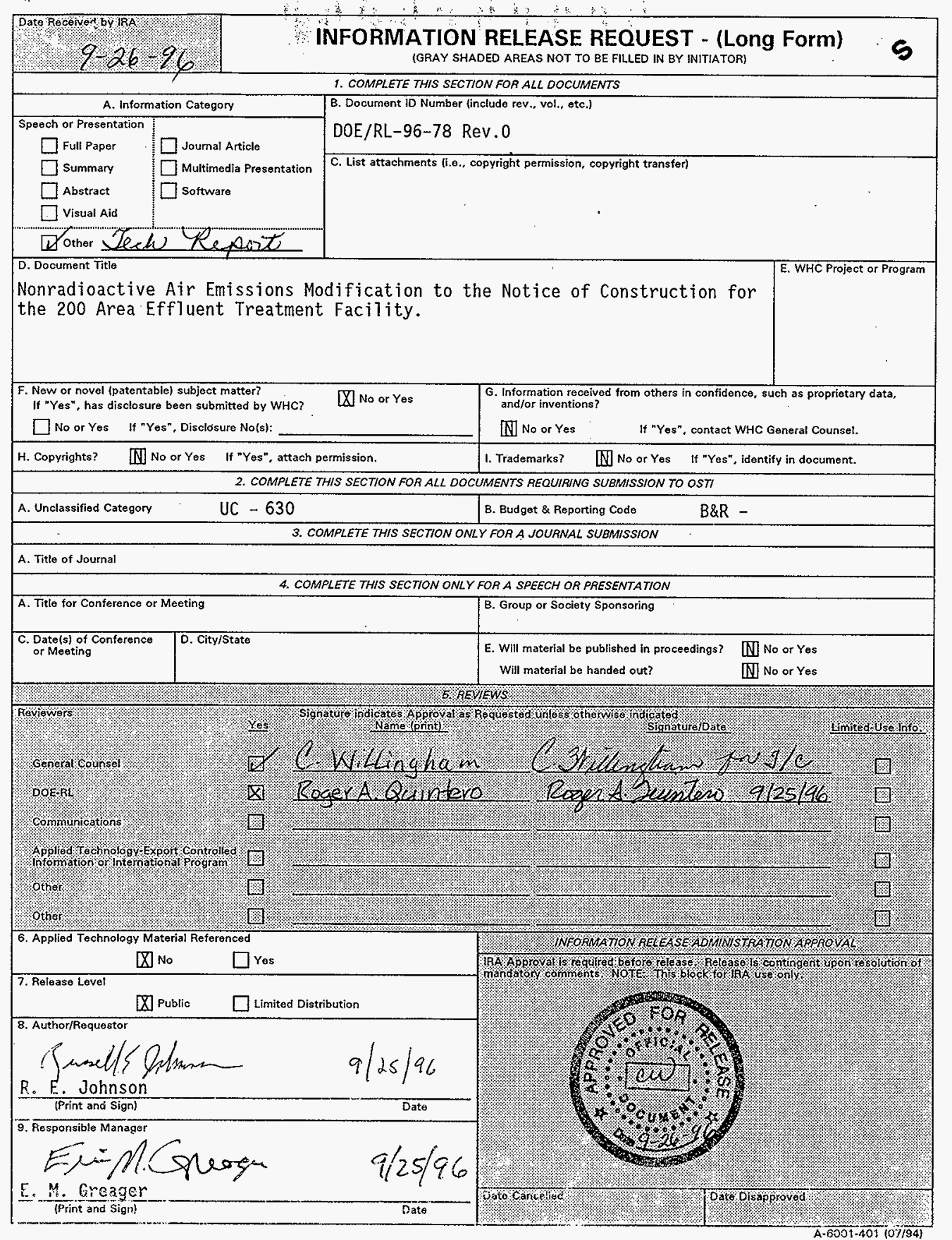


DOE/RL-96-78 Rev.0.

Document ID Number

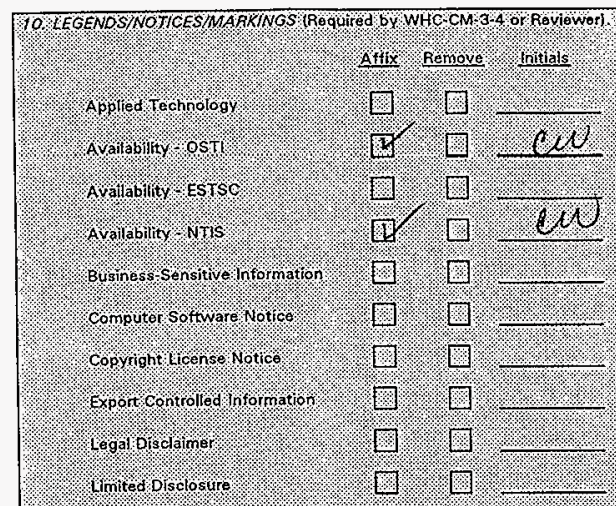

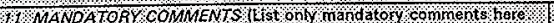

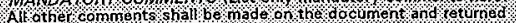
to tho whor

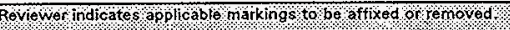

Affix nemover Initials

oiffoldusonty

Patents status

Profocisional normation

Programmatio Notice

Propnetan lnorimation

Puroose and Uso

Theosisidiss sitation

Tradomark oj sclamer

othor

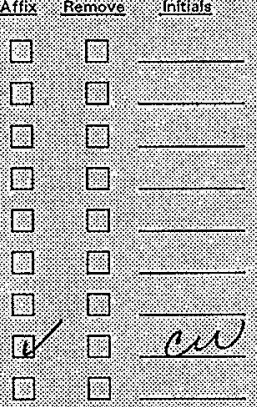

Rovower

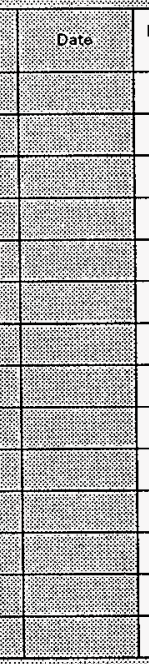

Resolved by Author/Requestor (Print \& Sign)
Date

12. AOOLTIONA \&INFORMATIONTOOMNENTS: 


\section{CONTENTS}

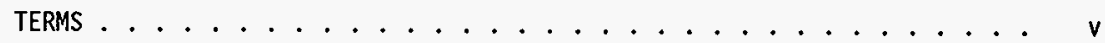

METRIC CONVERSION CHART ................... vi

1.0 FACILITY IDENTIFICATION AND LOCATION . . . . . . . . . 1

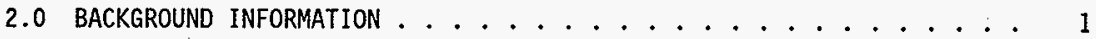

3.0 PROJECT INFORMATION .................. 5

3.1 PROCESS DESCRIPTION $\therefore \cdots$

3.2 VENTILATION AND EMISSIONS CONTROL SYSTEM DESCRIPTION $: \cdots$

3.3 MONITORING DESCRIPTION .................... 7

4.0 EMISSIONS ESTIMATION ........................ 7

4.1 CRITERIA POLLUTANTS PER WAC 173-400-030 $\cdots 7$

4.2 TOXIC AIR POLLUTANTS PER WAC $173-460-080 \ldots 8$

4.2.1 Toxic Air Pollutant Emissions from the Liquid Effluent Retention Facility ....... 8

4.2.2 Toxic Air Pollutant Emissions from the 200 Area Effluent Treatment Facility ........... 11

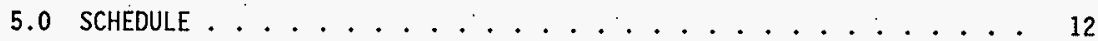

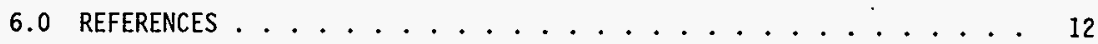

\section{FIGURES}

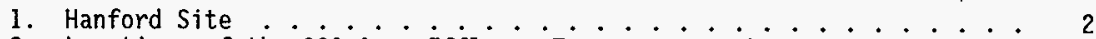

2. Locations of the 200 Area Effluent Treatment Facility, Liquid Effluent Retention Facility, and State-Approved Land

3. 200 Area Effluent Treatment Facijity Ventilation and Emissions

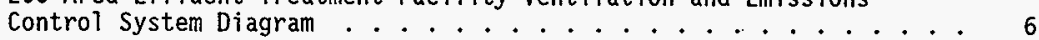

\section{TABLES}

1. Organic Toxic Air Pollutants Regulated Per WAC 170-460-080 . . . . 9 9

2. Inorganic Toxic Air Pollutants Regulated Per WAC 170-460-080 ... 10 
DOE/RL-96-78, Rev. 0

09/96

This page intentionally left blank. 


\section{TERMS}

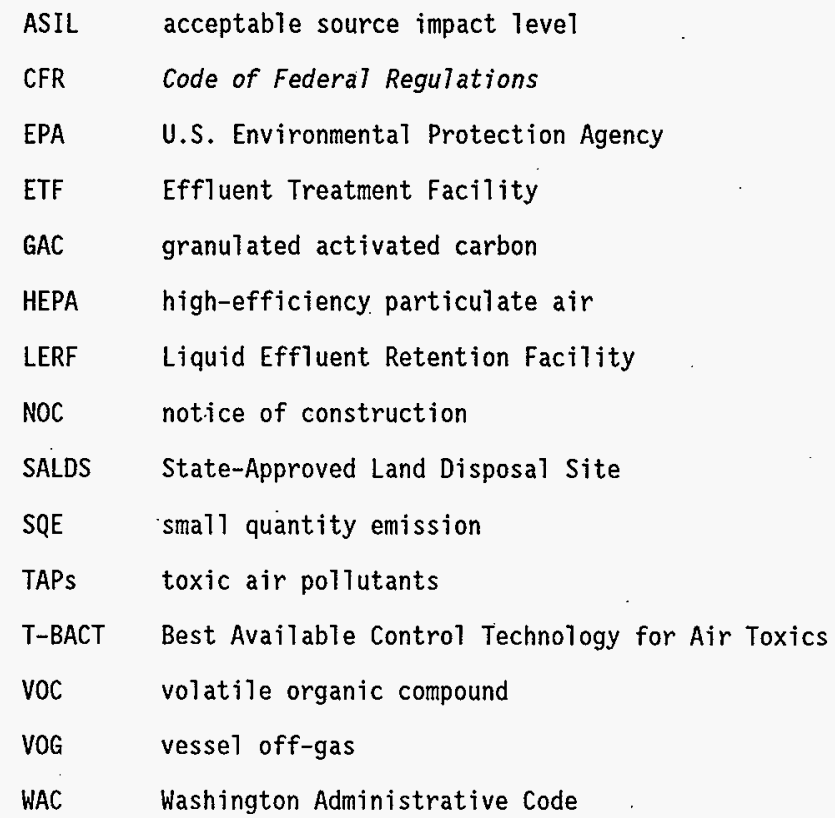




\begin{tabular}{|c|c|c|c|c|c|}
\hline If you know & $\begin{array}{l}\text { Multiply } \\
\text { by }\end{array}$ & To get & If you know & $\begin{array}{c}\text { Muttiply } \\
\text { by }\end{array}$ & To get \\
\hline \multicolumn{3}{|c|}{ Length } & \multicolumn{3}{|c|}{ Length } \\
\hline inches & 25.40 & millimeters & millimeters & 0.0393 & inches \\
\hline inches & 2.54 & centimeters & centimeters & 0.393 & inches \\
\hline feet & 0.3048 & meters & meters & 3.2808 & feet \\
\hline yards & 0.914 & meters & meters & 1.09 & yards \\
\hline mijes & 1.609 & kilometers & kilometers & 0.62 & miles \\
\hline \multicolumn{3}{|c|}{ Area } & \multicolumn{3}{|c|}{ Area } \\
\hline $\begin{array}{l}\text { square } \\
\text { inches }\end{array}$ & 6.4516 & $\begin{array}{l}\text { square } \\
\text { centimeters }\end{array}$ & $\begin{array}{l}\text { square } \\
\text { centimeters }\end{array}$ & 0.155 & $\begin{array}{l}\text { square } \\
\text { inches }\end{array}$ \\
\hline square feet & 0.092 & $\begin{array}{l}\text { square } \\
\text { meters }\end{array}$ & $\begin{array}{l}\text { square } \\
\text { meters }\end{array}$ & 10.7639 & $\begin{array}{l}\text { square } \\
\text { feet }\end{array}$ \\
\hline $\begin{array}{l}\text { square } \\
\text { yards }\end{array}$ & 0.836 & $\begin{array}{l}\text { square } \\
\text { meters }\end{array}$ & $\begin{array}{l}\text { square } \\
\text { meters }\end{array}$ & 1.20 & $\begin{array}{l}\text { square } \\
\text { yards }\end{array}$ \\
\hline $\begin{array}{l}\text { square } \\
\text { miles }\end{array}$ & 2.59 & $\begin{array}{l}\text { square } \\
\text { kilometers }\end{array}$ & $\begin{array}{l}\text { square } \\
\text { ki lometers }\end{array}$ & 0.39 & $\begin{array}{l}\text { square } \\
\text { miles }\end{array}$ \\
\hline $\begin{array}{l}\text { square } \\
\text { miles }\end{array}$ & 259 & hectares & hectares & 0.00391 & $\begin{array}{l}\text { square } \\
\text { miles }\end{array}$ \\
\hline acres & 0.404 & hectares & hectares & 2.471 & acres \\
\hline \multicolumn{3}{|c|}{ Pass (weight) } & \multicolumn{3}{|c|}{ Mass (weight) } \\
\hline ounces & 28.35 & grams & grams & 0.0352 & ounces \\
\hline pounds & 0.453 & kilograms & kilograms & 2.2046 & pounds \\
\hline short ton & 0.907 & metric ton & metric ton & 1.10 & short ton \\
\hline \multicolumn{3}{|c|}{ Volume } & \multicolumn{3}{|c|}{ Volume } \\
\hline $\begin{array}{l}\text { fluid } \\
\text { ounces }\end{array}$ & 29.57 & milliliters & milliliters & 0.03 & $\begin{array}{l}\text { fluid } \\
\text { ounces }\end{array}$ \\
\hline quarts & 0.95 & Titers & Titers & 1.057 & quarts \\
\hline galtons & 3.79 & liters & Titers & 0.26 & gallons \\
\hline cubic feet & 0.03 & $\begin{array}{l}\text { cubic } \\
\text { meters }\end{array}$ & $\begin{array}{l}\text { cubic } \\
\text { meters }\end{array}$ & 35.3147 & cubic feet \\
\hline $\begin{array}{l}\text { cubic feet } \\
\text { per minute }\end{array}$ & 0.02832 & $\begin{array}{l}\text { cubic } \\
\text { meters per } \\
\text { minute }\end{array}$ & & & \\
\hline cubic yards & 0.76 & \begin{tabular}{|l} 
cubic \\
meters
\end{tabular} & $\begin{array}{l}\text { cubic } \\
\text { meters }\end{array}$ & 1.308 & $\begin{array}{l}\text { cubic } \\
\text { yards }\end{array}$ \\
\hline \multicolumn{3}{|c|}{ Temperature } & \multicolumn{3}{|c|}{ Temperature } \\
\hline BTU/hour & $2.93 \mathrm{E}-4$ & kilowatts & & & \\
\hline Fahrenheit & $\begin{array}{l}\text { subtract } \\
32 \text { then } \\
\text { multiply } \\
\text { by } 5 / 9 \text { ths }\end{array}$ & Celsius. & Celsius & $\begin{array}{l}\text { multiply } \\
\text { by } \\
9 / 5 \text { ths, } \\
\text { then add } \\
32\end{array}$ & Fahrenheit \\
\hline
\end{tabular}

The following conversion chart is provided to the reader as a tool to aid in conversion.

Into metric units Out of metric units

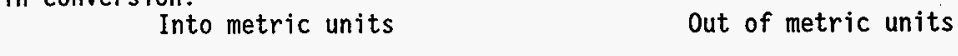

\section{METRIC CONVERSION CHART}


DOE/RL-96-78, Rev. 0

$09 / 96$

\title{
NONRADIOACTIVE AIR EMISSIONS \\ MODIFICATION TO THE NOTICE OF CONSTRUCTION \\ FOR THE 200 AREA EFFLUENT TREATMENT FACILITY
}

\subsection{FACILITY IDENTIFICATION AND LOCATION}

\author{
U.S. Department of Energy, Richland Operations Office \\ Hanford Site \\ 200 Area Effluent Treatment Facility \\ Richland, Washington 99352
}

The responsible manager's name and address are as follows:

Mr. T. K. Teynor, Director

Waste Programs Division

U.S. Department of Energy, Richland Operations Office

P.0. Box 550

Richland, Washington 99352

(509) $376-1366$.

The 200 Area Effluent Treatment Facility (ETF) is an industrial waste water treatment facility located in the 200 East Area on the Hanford Site. Associated with the ETF are the Liquid Effluent Retention Facility (LERF), al so located in the 200 East Area, and the State-Approved Land Disposal Site (SALDS) located in the 200 West Area. Figure 1 shows the locations of the 200 East and 200 West Areas within the Hanford Site. Figure 2 shows the locations of ETF, LERF, and SALDS within the 200 Areas.

\subsection{BACKGROUND INFORMATION}

This document serves as a modification to Notice of Construction (NOC) (DOE-RL 1992) pursuant to the requirements of WAC 173-400-110 and 173-460-040 for the expansion of approved influent streams to the ETF.

The ETF has an integrated system designed to treat a combination of dilute liquid waste streams generated on the Hanford Site by removing organic, inorganic, and radioactive contaminants. The ETF was designed to handle a maximum flow of 150 gallons per minute. The three waste streams in the original application were the 242-A Evaporator process condensate, the PUREX Plant process distillate discharge, and the PUREX Plant ammonia scrubber distillate. Although included in the design, the two PUREX Plant streams no longer exist and were eliminated when the decision was made to shut down the PUREX Facility. 


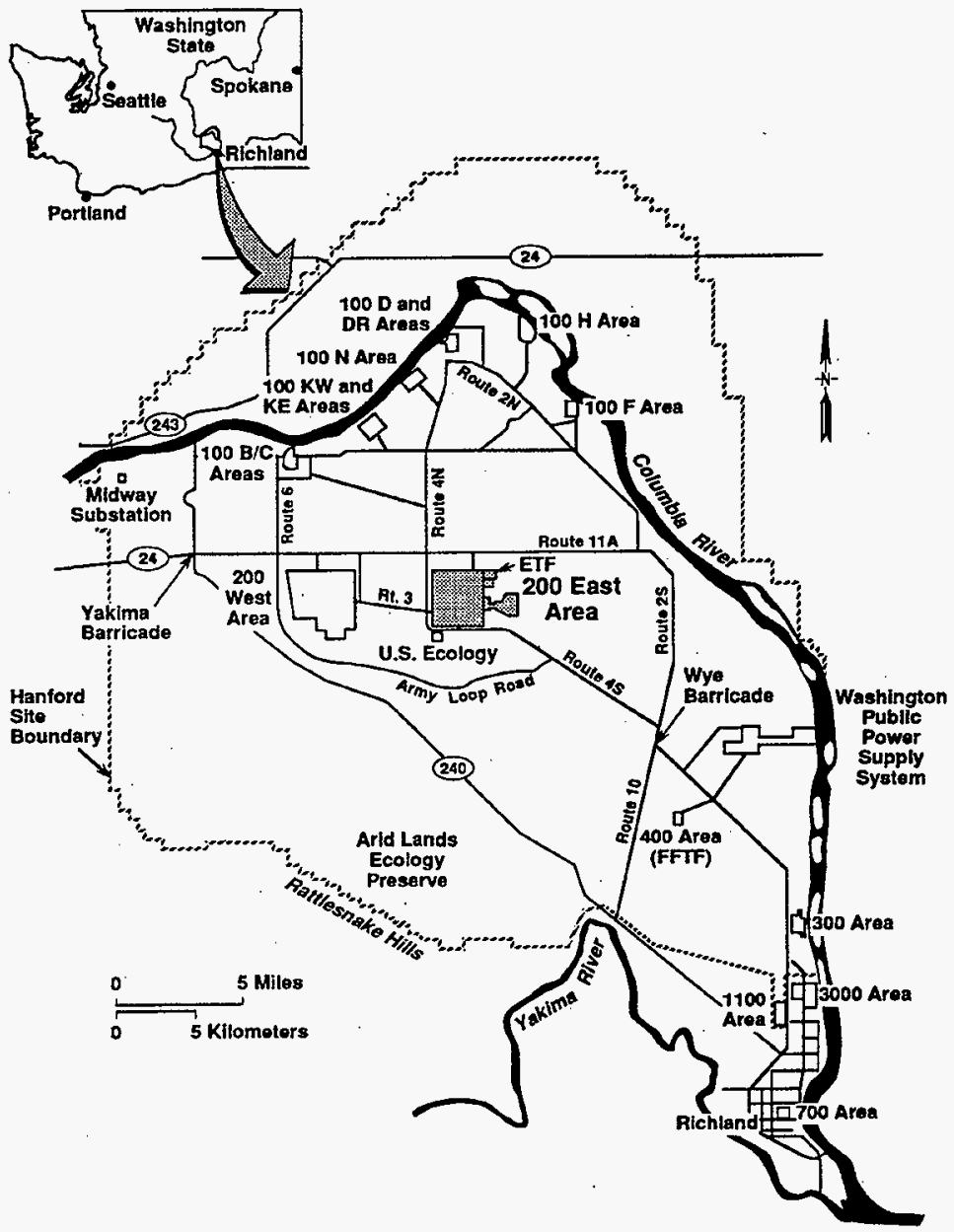

H96020397.2

Figure 1. Hanford Șite. 
DOE/RL-96-78, Rev. 0

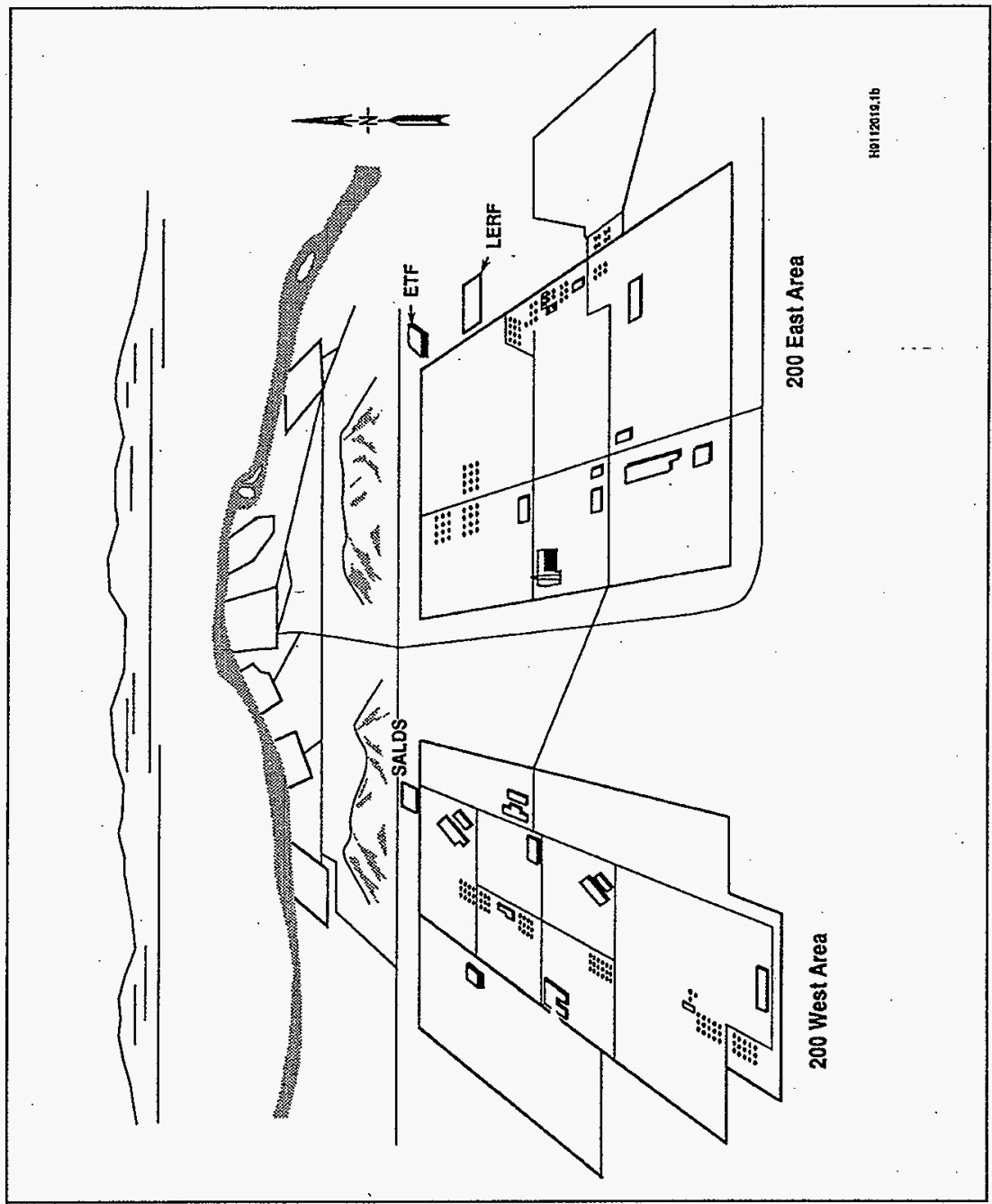

Figure 2. Locations of the 200 Area Effluent Treatment Facility, Liquid Effluent Retention Facility, and State-Approved Land Disposal Site in the 200 Areas. 
The nonradioactive air emissions NOC application for ETF (DOE-RL 1992) was submitted by the U.S. Department of Energy, Richland Operations Office (DOE-RL) on February 4, 1993, and was approved by the Washington State Department of Ecology (Ecology) (No. NOC-9393) on December 20, 1993. The permit approval conditions for volatile organic compound (VOC) emissions were Timited to 0.50 gram per minute and 0.55 gram per cubjc meter at standard conditions, measured at stream number $G 6$ of the ventilation offgas (VOG) system. The initial feed stream was comprised of effluent from the 242-A Evaporator and the LERF. The approved NOC accepted the proposed high-efficiency particulate air (HEPA) filters to control particulates. Because of the very small emission level's, there were no controls proposed for organic and inorganic vapors, which also were accepted. Ecology determined that the proposal met best available control technology for air toxics (T-BACT).

The State Waste Discharge Permit ST 4500, issued June 26, 1995, limited the discharge to the SALDS to the effluent from the treatment of 242-A Evaporator process condensate. On June 14, 1996 (DOE-RL 1996a) the DOE-RL requested Ecology to modify the permit to allow discharge by ETF to SALDS of treated groundwater from the 200-UP-1 aperable unit. Ecology made modifications to the discharge permit to allow the 200-UP-1 groundwater as an approved influent. Additional waste streams are being pursued in accordance with Section G.4 of Permit ST 4500 .

The Washington State Department of Health (DOH) regulates radionuclide emissions under WAC 246-247. The addition of the 200-UP-1 groundwater and $\mathrm{N}$-Basin water waste streams to LERF and ETF was approved by DOH as a streamlined NOC modification on June 11, 1996, which was later expanded to include transfers from other locations.

This NOC modification involves a minor change in constituents, but no change in treatment or T-BACT analysis. The LERF will not exceed acceptable source impact levels (ASILS). The ETF will control VOC emissions to current permit requirements. The ETF will use HEPA filters to control particulates, as well as granulated activated carbon (GAC) filters to control VOC emissions. The VOG filter unit includes a charcoal bed filter between the HEPA filters in the VOG system; previously this was not included as VOC control equipment.

As an operational change, batch waste streams (e.g., minor changes in raw material composition) from various locations on the Hanford Site will be treated at ETF. The batches will be characterized and evaluated before treatment to ensure that permit conditions are met. Following characterization, the waste water will be transferred via truck from various locations to the ETF truck unloading area, and accumulated at the LERF, if necessary, before treatment at ETF. ETF has a treatment capacity of 216,000 galions per day. The batch waste streams, anticipated to be a few thousand gallons a few times a month, represent a small percentage of the approved treatment capacity. The batch waste streams will meet the new source review exemption found in WAC $173-460-040(2)(c)$. 
The State Environmental Policy Act of 1971 checklist that was prepared for ETF in July 1992 was deemed adequate; no further information was required for this NOC modification.

\subsection{PROJECT INFORMATION}

A description of the LERF and ETF processes, ventilation and emission control systems, and monitoring is provided in the following sections.

\subsection{PROCESS DESCRIPTION}

The LERF was built before September 1991, for holding effluent from the 242-A Evaporator until ETF was constructed.

The LERF was built before the effective date of WAC 173-460, so an NOC for nonradioactive emissions was not submitted. The LERF was included as part of the process for 242-A Evaporator waste effluent to be treated at the ETF, and is specifically listed as an approved effluent source for ETF in NOC-93-3. The addition of new waste streams to LERF will not cause an increase in actual toxic air pollutant (TAP) emissions. The design of the unit prevents TAP emissions from exceeding the ASILS for any constituents, as discussed in Section 4.2.1.

A detailed description of the ETF process is found in the original NOC application (DOE-RL 1992). To summarize, the primary treatment train provides for feed storage, suspended solids removal, ultraviolet/oxidation with hydrogen peroxide, $\mathrm{pH}$ adjustment, degasification, reverse osmosis (RO), ion-exchange polishing, final $\mathrm{pH}$ adjustment, and effluent storage. A secondary treatment train provides evaporation of product solids (e.g. RO reject and resin regenerating solutions) to dryness. A11 of the process components contain vents that tie into the VOG (Figure 3 ).

As noted in the modification request for ST 4500 (DOE-RL 1996a), inorganic compounds are treated at the ETF by a combination of reverse osmosis and ion exchange with an overall removal efficiency between 99 and 99.9 percent for inorganic constituents of concern.

Organic compounds, such as carbon tetrachloride, are treated in several locations at ETF. The majority are destroyed in the ultraviolet/oxidation system. The VOC compounds not completely destroyed by the ultraviolet/oxidation will be removed in the degasification system step and captured on the VOG carbon filters. Finally, the RO unit is also effective in treating organic compounds. As noted in the modification request for ST 4500 (DOE-RL 1996a), the ETF treatment systems should effectively treat the expected concentration of carbon tetrachloride in the 200-UP-1 groundwater. 


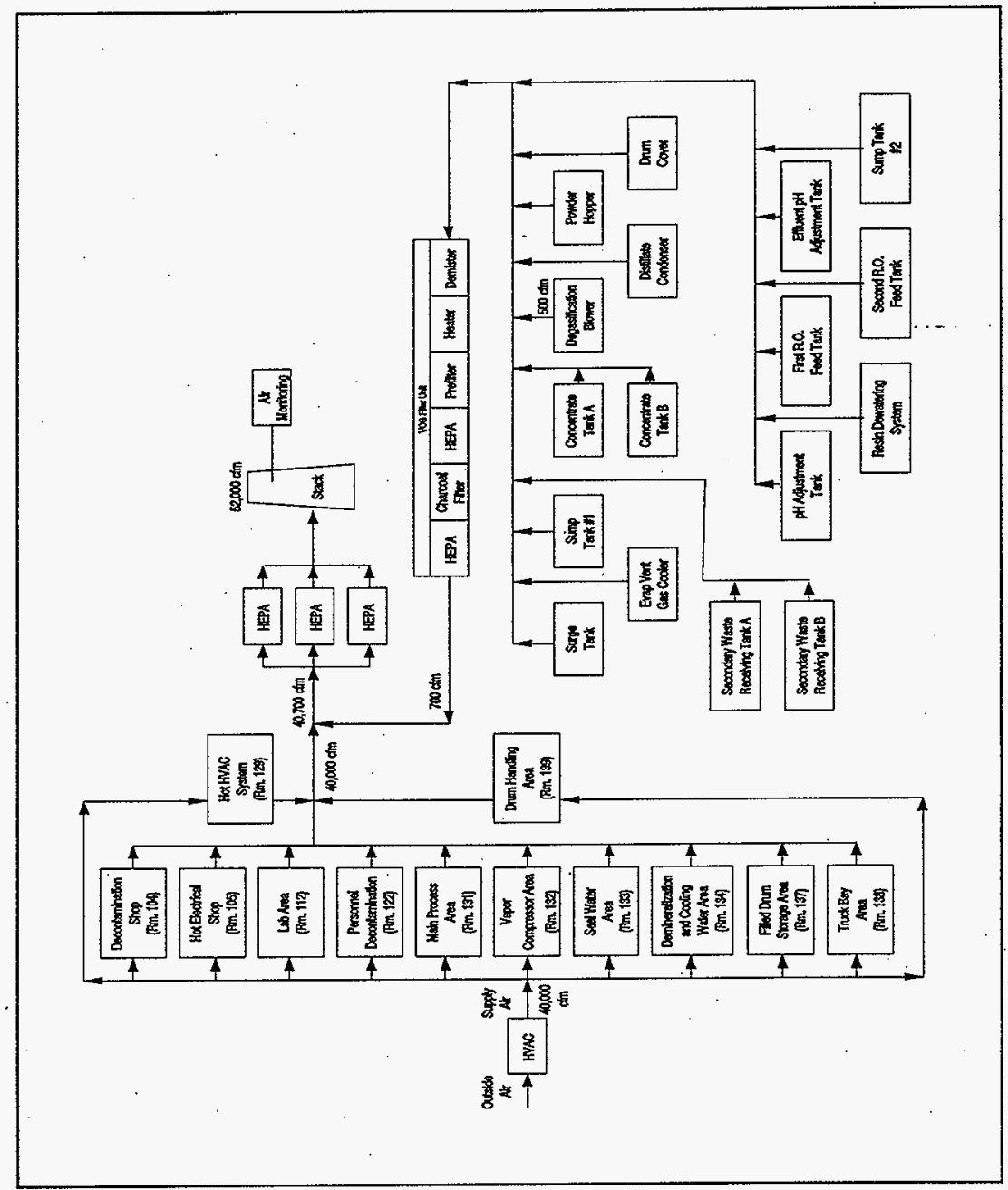

Figure 3. 200 Area Effluent Treatment Facility Ventilation and Emissions Control System Diagram. 


\subsection{VENTILATION AND EMISSIONS CONTROL SYSTEM DESCRIPTION}

The LERF consists of three retention basins, each with a 6.5 million gallon capacity. Each basin has a floating cover, with a relatively small, passively vented breather space with intermittent use. The breather vents operate at a maximum flow of 1 cubic foot per minute, whenever effluent is transferred to the basins. Also, there are daily and seasonal cycles of expansion and contraction that contribute to the passive ventilation at a lower flow rate. Each breather vent is equipped with a drum containing 200 pounds of granulated activated carbon (GAC). The GAC canisters are expected to last the life of the facility without requiring a changeout.

Gaseous emissions from ETF are controlled by the VOG system, which is connected to each potential source of gaseous emissions. A slight negative pressure in each tank and vessel where gaseous waste can be released prevents any fugitive emissions. ATl collected emissions are treated before release.

The VOG system treats gaseous emissions through the VOG Filter Unit. The filter unit contains a prefilter, a charcoal bed filter and two HEPA filters. The VOG system is described in more detail in the original NOC application (DOE-RL 1992).

\subsection{MONITORING DESCRIPTION}

Monitoring is performed at ETF within the VOG system after treatment and before entry into the facility HVAC discharge system and before release from the facility. The emissions from the VOG are monitored for temperature and flow. Radioactivity is monitored continuously at the HVAC exhaust stack via a paper filter sampler.

The performance tests for VOC emissions required by NOC-93-3 were completed on January 23, 1996, and reported to Ecology (DOE-RL 1996b). Permit conditions were met.

\subsection{EMISSIONS ESTIMATION}

The potential emissions for LERF and ETF are calculated by assuming the entire volume of the two additional waste streams is at the highest concentration found. Actual emissions are estimated for constituents of concern based on removal efficiencies and transfer rates described in the original NOC application (DOE-RL 1992) and the ST 4500 modification request (DOE-RL 1996a). Emissions at either facility will not exceed ASILS for any TAPs, so dispersion modeling will not be required.

\subsection{CRITERIA POLLUTANTS PER WAC 173-400-030}

Only one criteria pollutant, VOCs, has a potential to be emitted by LERF or ETF. The increased potential to emit, based on total organic compound 
concentrations in the proposed effiuent waste streams, is less than 500 pounds, well below the Prevention of Significant Deterioration trigger level of 40 tons per year specified in WAC 173-400-030.

\subsection{TOXIC AIR POLLUTANTS PER HAC 173-460-080}

The TAP emissions are anticipated to be in gaseous form. Tables 1 and 2 list the potential organic and inorganic TAP emissions from the proposed 200-UP-1 groundwater (26 million gallons) and the $\mathrm{N}$-Basin water $(1.4 \mathrm{mill}$ ion gallons, including the emergency dump basin). The tables contain the list of constituents, the maximum concentration in the untreated effluent, and whether the constituent is a new TAP or an increase in concentration from a previously listed TAP in the original NOC application (DOE/RL-92-69). If either condition is true, the constituent's TAP class, ASIL, the corresponding small quantity emissions (SQE) rate, and the potential mass inventory of each constituent is also 1 isted. The potential untreated mass of a constituent is calculated by assuming all 27.4 million gallons of the untreated effluent was at the highest concentration found in the 200-UP-1 groundwater, with the exception of barium and lead. For these two constituents, which had a higher concentration in the $\mathrm{N}$-Basin water, a weighted average was used.

Constituents that have a mass in the untreated effluent that is less than the SQE cannot exceed the SQE at the point of emission for either LERF or ETF, and do not warrant further discussion. Constituents with a potential inventory that could exceed the SQE, or if an SQE is not established, are highlighted in the tables with shading, and are discussed in the following section.

\subsubsection{Toxic Air Pollutant Emissions from the Liquid Effluent Retention Facility}

Inorganic TAPs that potentially could exceed SQE rates (or where one doesn't exist) include beryllium, cadmium, calcium, chromium, iron, lead, nickel, and uranium. All of these constituents would exist as soluble salts, with vapor pressures of zero. There is no potential for these constituents to be released from LERF.

Organic TAPs that do not have SQE rates established include aldrin, dieldrin, and heptachlor. Release fractions calculated from Henry's Law constants are five to eight orders of magnitude lower than the potential inventory release. Pesticides were detected only in one groundwater sample. Even if the entire 27.4 million gallons of the two proposed waste streams had the maximum concentration found, and assuming the breather vents operated at 1 cubic foot per minute continuously for an entire year, rather than 
Table 1. Organic Toxic Air Pollutants Regulated Per WAC 170-460-080.

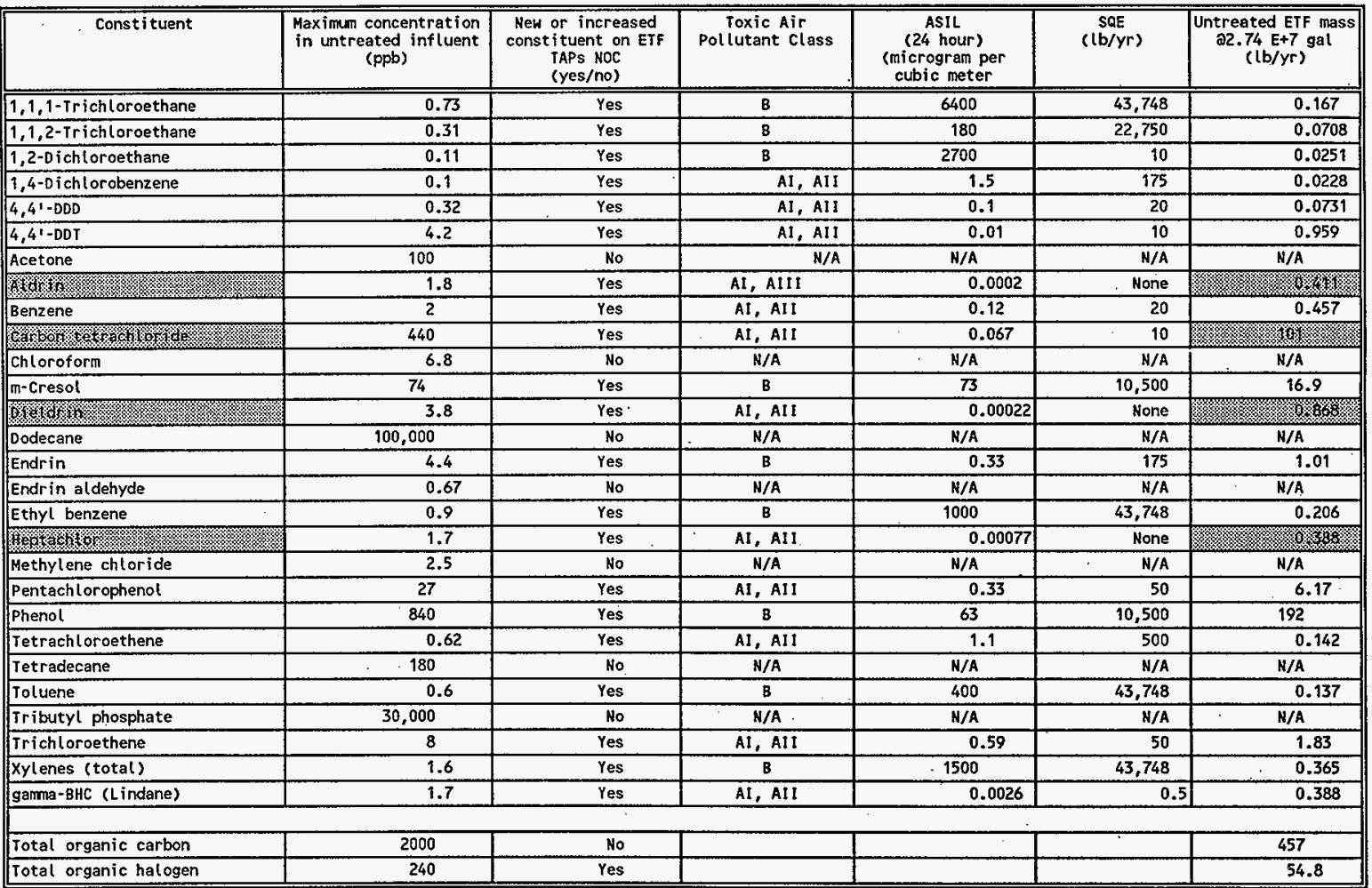

ETF = effluent treatment facility.

$\mathrm{ppb}=$ parts per billion.

TAPS = toxic air pollutants.

ASIL = acceptable source impact leve1.

$\mathrm{SQE}=$ small quantity emissions. 
Table 2. Inorganic Toxic Air Pollutants Regulated Per WAC 170-460-080.

\begin{tabular}{|c|c|c|c|c|c|c|}
\hline Const ituent & $\begin{array}{c}\text { Maximum concentration } \\
\text { in untreated influent } \\
\text { (ppb) }\end{array}$ & $\begin{array}{l}\text { New or increased } \\
\text { consti tuent on ETF } \\
\text { TAPS NOC } \\
\text { (yes/no) }\end{array}$ & $\begin{array}{l}\text { Toxic Air } \\
\text { Pollutant class }\end{array}$ & $\begin{array}{c}\text { ASIL } \\
\text { (24 hour) } \\
\text { (microgram per } \\
\text { cubic meter }\end{array}$ & $\begin{array}{c}\text { SQE } \\
(\text { (b/yr })\end{array}$ & $\begin{array}{c}\text { Untreated ETF mass } \\
22.74 \mathrm{E}+7 \text { gal } \\
\text { (lb/yr) }\end{array}$ \\
\hline Aluminum & 240 & No & N/A & N/A & $\mathrm{N} / \mathrm{A}$ & $N / A$ \\
\hline Ant imony & 100 & No & $\mathrm{N} / \mathrm{A}$ & N/A & $\mathrm{N} / \mathrm{A}$ & $\mathrm{N} / \mathrm{A}$ \\
\hline $\begin{array}{l}\text { Barium } \\
\text { (N-Basin a } 2590 \mathrm{ppb})\end{array}$ & 300 & Yes & $\mathbf{B}$ & 1.7 & 175 & 99.5 \\
\hline H. & 1.9 & Yes & AI, AII & 0.00042 & None & 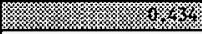 \\
\hline Boron & 70 & No & N/A & N/A & N/A & M/A \\
\hline Bronide & 400 & No & N/A & $N / A$ & $\mathrm{~N} / \mathrm{A}$ & N/A \\
\hline G & 7.2 & Yes & AI, AII & 0.00056 & None & 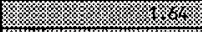 \\
\hline X & 330,000 & No & N/A & 6.7 & 175 & 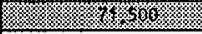 \\
\hline Chloride & 59,000 & No & N/A & $\mathrm{N} / \mathrm{A}$ & N/A & N/A. \\
\hline 1ffin & 180 & Yes & AI, AI I & 0.000083 & None & 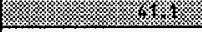 \\
\hline Cobalt & 5 & No & $\mathrm{N} / \mathrm{A}$ & $N / A$ & N/A & $\mathrm{N} / \mathrm{A}$ \\
\hline Copper & 790 & No & $\mathrm{N} / \mathrm{A}$ & $N / A$ & N/A & N/A \\
\hline Cyanide & 10 & No & N/A & $N / A$ & $\mathrm{~N} / \mathrm{A}$ & N/A \\
\hline Fluoride & 4,000 & No & N/A & $N / A$ & $N / A$ & N/A \\
\hline 6/n r & 9,400 & Yes & B & 3.3 & 175 & 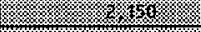 \\
\hline 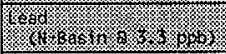 & 0.0 & Yes & AI, AIII & 0.5 & None & 64 \\
\hline Magnes itum & 110,000 & No & N/A & N/A & N/A & N/A \\
\hline Manganese & 33 & No & N/A & $N / A$ & N/A & $N / A$ \\
\hline (1) & 120 & Yes & AI, AII & 0.0021 & 0.5 & 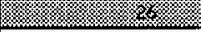 \\
\hline Nitrate & $1,700,000$ & No & $N / A$ & $N / A$ & $\mathrm{~N} / \mathrm{A}$ & N/A \\
\hline Nitrite & 12,000 & No & N/A & $N / A$ & $\mathrm{~N} / \mathrm{A}$ & N/A \\
\hline Potassium & 13,000 & No & N/A & N/A.1 & N/A & N/A \\
\hline silver & 6.1 & Yes & B & 0.033 & 175 & 1.39 \\
\hline Sodium & 59,000 & No & $N / A$ & N/A & N/A & N/A \\
\hline Strontium & 1,270 & No & N/A & $\mathrm{N} / \mathrm{A}$ & $\mathrm{N} / \mathrm{A}$ & N/A \\
\hline Sulfate & 84,000 & No & N/A & $\mathrm{N} / \mathrm{A}$ & $\mathrm{N} / \mathrm{A}$ & N/A \\
\hline 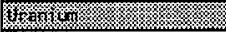 & 16,400 & Yes & B & 0.67 & 175 & 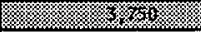 \\
\hline Vanadium & 40 & Yes & $B$ & 0.17 & 175 & 9.14 \\
\hline Zine & 330 & Yes & $\mathrm{B}$ & 0.033 & 175. & 75.4 \\
\hline
\end{tabular}

ETF = effluent treatment facility.

ppb = parts per billion.

TAPS = toxic air pollutants .

ASIL = acceptable source impact level.

SQE = small quantity emissions. 
1

intermittently for a shorter period, the total amount of pesticides that could even challenge the GAC canisters is only about a gram. Releases of these constituents are not considered feasible.

The only new constituent that has the potential to exceed an established SQE is carbon tetrachloride. The 200-UP-1 groundwater has a potential inventory of carbon tetrachloride of about 100 pounds. Most of this would stay in the effluent that will be transferred to ETF, as it would not remain at LERF long enough to escape. Even if the entire amount escaped through the breather vents, the capacity of the GAC canisters is more than adequate to capture all of it. The actual releases from LERF would be negligible. The ASILS would not be exceeded for any TAP constituents for any waste stream likely to be sent to LERF.

\subsubsection{Toxic Air Pollutant Emissions from the 200 Area Effluent Treatment Facility}

Inorganic TAPS that could potentially exceed SQE rates (or where one doesn't exist) include beryllium, cadmium, calcium, chromium, iron, lead, nickel, and uranium. Calcium and chromium were discussed in Appendix $B$ of the original NOC application (DOE-RL 1992). Calculations for these two constituents, present at 2,800 and 66 parts per billion, respectively, in the 242-A Evaporator process condensate, demonstrated that releases from ETF would be below the ASILS or SQE rates. The ETF, processing this waste stream at a maximum capacity of 150 gallons per minute for the entire year, would result in a maximum concentration in the release of $2.8 \mathrm{E}-6$ micrograms per cubic meter for calcium and 6.6 E-8 micrograms per cubic meter for chromium. With a flowrate of 27,250 standard cubic feet per minute, this would correspond to an annual release of $2.5 \mathrm{E}-06$ pounds per year for calcjum and $5.9 \mathrm{E}-08$ pounds per year for chromium. The maximum concentrations in the 200-UP-1 groundwater for calcium and chromium were 330,000 parts per billion and 180 parts per billion, respectively. Using the same transfer rate and mechanism, the maximum concentration in the ETF release would be 3.3 E-04 micrograms per cubic meter for calcium and 1.8 E-07 micrograms per cubic meter for chromium, both well below the respective ASILS.

The same transfer rate (1 E-12 micrograms per cubic meter gaseous effluent per parts per billion liquid effluent) applied to the other inorganic constituents yields values well below ASILS.

Organic TAPs will be treated very effectively by ETF. The pesticides (aldrin, dieldrin, and heptachlor) that do not have established SQE rates should be destroyed completely by ultraviolet/oxidation. Because of the low vapor pressures of these constituents, residual undestroyed levels would stay in the water phase and be removed by the RO. It is unlikely that any detectible amounts would even challenge the charcoal bed filter in the VOG filter unit. Carbon tetrachloride also would be effectively treated. The potential inventory from the 200-UP-1 groundwater is about 100 pounds. The SQE rate for carbon tetrachloride is 10 pounds per year. The required removal efficiency to stay under the SQE is 90 percent. As stated in the modification 
request for ST 4500 (DOE-RL 1996a), the ETF treatment systems should remove greater than 99.9 percent of the expected concentration of carbon tetrachloride in the 200-UP-1 groundwater.

\subsection{SCHEDULE}

The piping changes needed to allow transfer of the 200-UP-1 groundwater to LERF are scheduled to begin October 1, 1996 (no emission potential for this phase). Treatment of the two new waste streams at ETF would begin as early as January 1997.

\subsection{REFERENCES}

DOE-RL, 1992, Notice for Approval to Construct the 242-A Evaporator/PUREX. Plant Process Condensate Treatment Facility, DOE/RL-96-62, Rev. 0, U.S. Department of Energy, Richland Operations office, Richland, Washington.

DOE-RL, 1996a, Letter, "Characterization Study Under State Waste Discharge Permit ST 4500", dated June 14, 1996, J.E. Rasmussen, U.S. Department of Energy; Richland Operations Office, Richland, Washington to D.S. Dougherty, Washington State Department of Ecology, Olympia, Washington.

DOE-RL, 1996b, Letter, "200 Area Effluent Treatment Facility (ETF) U.S. EPA Reference Method 9 and 25A Test Report", dated March 11, 1996, J.E. Rasmussen, U.S. Department of Energy, Richland Operations Office, Richland, Washington to J.S. Stohr, Washington State Department of Ecology, Olympia, Washington. 


\section{DISTRIBUTION}

OFFSITE

MSIN

J. S. Stohr

Hanford Project Manager

Washington State Department of Ecology

P. 0. Box 47600

Oiympia, Washington 98504-7600

J. Wilkinson

Confederated Tribes of the Umatilla

Indian Nation

P. 0. Box 638

Pendieton, Oregon 97801

D. Powaukee

Nez Perce Tribe

P. 0. Box 365

Lapwai, Idaho 93540

R. Jim, Manager

Environmental Restoration/

Waste Management Program

Yakama Indian Nation

P. 0. Box 151

Toppenish, Washington 98948

ONSITE

U.S. Department of Energy,

Richland Operations Office

G. M. Bell

R. N. Kreke1

A5-52

R. A. Quintero

A5-15

H. M. Rodriguez

S7-55

T. K. Teynor

A5- 15

Reading Room (2)

S7-55

$\mathrm{H} 2-53$ 


\section{DISTRIBUTION (cont)}

ONSITE

MSIN

Pacific Northwest National Laboratory

Hanford Technical Library

$\mathrm{K} 1-11$

Westinghouse Hanford Company

D. L. Flyckt

R. E. Johnson (5)

E. M. Greager

D. W. Lindsey

Air Operating Permit File

DPC

EDMC

S6-21

H6-25

H6-25

S6-71

H6-25

A3-94

H6-08 